\title{
A Review of Medusa's Hair
}

In her review of my book, Medusa's Hair: An Essay on Personal Symbols and Religious Experience (JAS 42, no. 2 [1983]: 442-44), Margaret Trawick Egnor takes issue with my use of psychoanalysis in the study of cultural symbols. She says that she is a "non-Freudian" and also a skeptic as far as psychoanalysis is concerned (p. 443). Yet she ends up by psychoanalyzing the author. In relation to one of my informants, Sada Sami, Egnor says: "In this rare personage he [Obeyesekere] quickly learns to see a 'myth dreamer,' a 'Gawain,' a 'Saint George,' a 'Perseus cutting off Medusa's head with its swarms of snake hair,' and finally a conqueror of 'his father, a huge monster who will not permit him to take on a new office.' Yet none of these grandiose appellations fits at all the man that Obeyesekere describes. Rather it seems that, in his vision of this informant, the anthropologist has found himself." The implication is clear: it is myself that I present in my informant, and it is my hang-up with my father that I describe.

Much of this is Egnor's own invention. In my book I state clearly that Sada Sami is not an inventor of myths, "the evidence does not warrant such an inference" (p. 190). $\mathrm{He}$ is a myth dreamer, someone who dreams myths from a preexisting repertoire, and I gave two examples of his myth dreams. As for identifying him with other wellknown heroes of myth, my text reads as follows: "One cannot but be struck by the similarity of Sada Sami's adventures with other heroes of myth-Perseus cutting off Medusa's head with its swarms of snake hair, or Gawain's encounter with the Green Knight, or Saint George's with the dragon. [These] were also probably spiritual adventures like Sada Sami's but narrated as if they were real" (p. 190).

Similarity is not identity, and the intention of the chapter, and the preceding one, was to show that myths often derive from dreams as dreams derive from myths. The "grandiose appellations" given to Sada Sami are Egnor's, not mine.

Egnor's review is full of similar distortions of my position, but I think one must protest when a professional review has sunk to the level of a gratuitous psychoanalysis of the author.

Gananath Obeyesekere

Princeton University

\section{A Response to Gananath Obeyesekere}

When I read Medusa's Hair, I was greatly impressed by Professor Obeyesekere's honesty, courage, and compassion in his relations with and portrayal of his informants, and I hope that my admiration was conveyed in my review. At the same time, I was disturbed by some of his judgments regarding these informants-a reaction no doubt intensified by my oun "hang-ups" with $m y$ father (a Freudian psychiatrist).

In particular, I was concerned with the degree to which Freudian theory can help us understand the hearts of women and of non-European people of either sex. I would certainly not reject Freud's ideas or his methodology in toto.

I am especially sorry that Obeyesekere perceived as an attack my suggestion that he saw himself in one of his informants. I do not know whether Obeyesekere desires to conquer his father. What I was thinking of when I made this suggestion was his 